\title{
PENGARUH PERMAINAN LASY TERHADAP PENINGKATAN KONSENTRASI PADA ANAK AUTIS
}

\author{
Rina Rokhimah dan Ira Darmawanti \\ Program Studi Psikologi Universitas Negeri Surabaya
}

\begin{abstract}
Children with autistic disorder usually have some problems with their concentration. They feel difficult to focus in doing some tasks. Thus, it may have a huge impact when they are at school. This study was aimed to determine the effects of lasy game in increasing autistic children's concentration level. This study used pre-experiment method with one group pretest-posttest design. Five children with autism in a therapy center were recruited as participants of this study. Independent variable is a game called lasy game and dependent variable is concentration level. Collecting data using an observation sheet (rating scale of concentration level) with statistic test using wilcoxon assigned rank test. The study result of Wilcoxon analysis Asymp. Sig (2 tailed) is 0,043, which can be said as a significant result because of Asymp Sig (2 tailed) 0,043 less than 0,05 $(0,043<0,05)$. This shows that there is a difference of concentration level between before and after the intervention of lasy game. It can be concluded from this research that the game has been produced for increasing concentration level among children with autistic disorder.
\end{abstract}

Keywords: Lasy game, concentration level, children with autistic disorder.

\begin{abstract}
Abstrak: Anak dengan gangguan autis mengalami keterlambatan dalam aspek kognitifnya, diantaranya berdampak pada terjadinya gangguan pada tingkat konsentrasi. Gangguan konsentrasi ini berdampak sangat besar terutama pada proses pembelajaran di sekolah. Tujuan penelitian ini adalah untuk mengetahui pengaruh permainan lasy terhadap peningkatan konsentrasi pada anak autis. Pada penelitian ini menggunakan metode pre-eksperimen dengan one group, pretest-posttest desain. Populasi pada penelitian ini adalah anak autis sebuah pusat terapi dengan jumlah 5 subjek anak penyandang autis. Variabel bebas dalam penelitian ini adalah permainan lasy dan variabel terikat adalah tingkat konsentrasi. Pengambilan data dalam penelitian ini menggunakan lembar observasi (rating scale tingkat konsentrasi) dengan uji statistik Wilcoxon Signed Rank Test. Hasil dari Wilcoxon analysis Asymp. Sig (2 ekor) adalah 0.043. Hasil analisis ini adalah signifikan karena kurang dari $0,05(0,043<0,05)$. Hal ini menunjukkan bahwa terdapat perbedaan sebelum dan sesudah diberikan permainan lasy. Kesimpulan penelitian ini ada pengaruh permainan lasy terhadap peningkatan konsentrasi pada anak autis. Berdasarkan hasil penelitian, maka terapi bermain yang berupa permainan lasy dapat dijadikan sebagai intervensi dini yang dapat dilakukan oleh orang sekitar untuk membantu menangani gangguan konsentrasi pada anak autis.
\end{abstract}

Kata kunci: Permainan lasy, tingkat konsentrasi, anak autis.

Penelitian mengenai autisme telah dilakukan selama 60 tahun yang lalu. Pada tahun 1912 seorang psikiater dari Swiss Eugene Bleuler menemukan pola individu penyandang skizofrenia yang tampaknya mementingkan diri sendiri dan Bleuler merupakan orang pertama yang membuat istilah autis. Namun, pada tahun 1943 Leo Kanner psikolog dari Austria mempublikasikan autisme sebagai gangguan mental independen (Mustajib, 2010). Karakteristik yang digunakan oleh Kanner dalam kelompok penelitiannya memiliki gambaran awal bahwa anak autis secara 
umum mempunyai memori yang bagus layaknya anak normal bahkan lebih dari itu serta perilaku yang kompleks yang dimiliki oleh setiap anak autis. Pada tahun 1970 penelitian mulai menyebar ke Swedia, Selama penelitian para peneliti menemukan bahwa autisme lebih kompleks dari yang disadari. Akibat dari penelitian ini para peneliti mengetahui bahwa ada lebih dari satu perilaku yang dimiliki anak autis tersebut, yaitu kecenderungan dalam atensi, kesulitan dalam berkonsentrasi, dan kesulitan dalam tetap bertahan dalam mengerjakan sesuatu atau tugas-tugas tertentu (Bektiningsih, 2009).

Kini jumlah penderita autis selalu mengalami peningkatan dari tahun ke tahun. Pada tahun 1987 prevalensi penyandang autis adalah 1 anak per 10.000 kelahiran. Penderita autis sepuluh tahun kemudian meningkat menjadi 1 anak per 500 kelahiran. Dan penelitian selanjutnya pada tahun 2000 menjadi 1 per 250 kelahiran. Menurut laporan Central for Disease Control (CDC) di Amerika serikat (dalam Ningsih, 2007), penderita autis kini mencapai 1 anak per 150 kelahiran dan diperkirakan angka yang sama juga terjadi di negara lain.

Di Indonesia khususnya setiap tahun jumlah penyandang autis terus mengalami peningkatan. Hasil penelitian Budhiman (2001) menunjukkan angka kejadian autisme yang pada tahun 1987 penderita autisme 1:500 anak dan pada tahun 2001 menjadi 1:150 anak, pada tahun 2003 telah mencapai 152 per 10.000 anak $(0,15-0,2 \%)$. Jumlah ini menunjukkan peningkatan yang tajam dibanding sepuluh tahun yang lalu yang hanya 2-4 per 10.000 anak. Melihat angka tersebut, dapat diperkirakan di Indonesia setiap tahun akan lahir lebih kurang 69.000 anak dengan autisme (Hadiyanto, 2003). Berdasarkan perkembangan keadaan khusus yang dimiliki anak dengan gangguan ini, mereka perlu mendapat perhatian khusus dari para ahli. Terutama dari aspek konsentrasi autisme, dimana pada aspek konsentrasi tersebut dapat menentukan keefektifan pada saat proses belajar.

Dugaan tentang adanya kelainan otak pada anak autis ini dinyatakan juga oleh 17 penelitian yang dilakukan di sepuluh pusat penelitian, antara lain di Kanada, Prancis dan Jepang yang melibatkan 250 penyandang autisme dimana pada kebanyakan dari mereka ditemukan pengecilan pada daerah cerebellum yang menyebabkan kacaunya lalu lalang impuls di otak. Cerebellum bukan saja mengatur keseimbangan, tapi juga ikut berperan dalam proses sensorik, berfikir, daya ingat, belajar, berbahasa dan juga perhatian serta konsentrasi. Ketidakmampuan anak penyandang autis untuk mengalihkan perhatian atau berkonsentrasi pada hal yang lain dengan cepat merupakan ciri khas dari anak autis (Budiman, 2001).

Dharmono (2010) mendefinisikan konsentrasi sebagai usaha yang diperlukan untuk mengarahkan aktivitas mental pada pengalaman tertentu. Pada penyandang autisme, memiliki pengaruh yang besar terhadap proses pembelajaran. Jika anak penyandang autis kesulitan dalam berkonsentrasi, maka jelas terlihat kegiatan yang dilakukan akan sia-sia, apalagi saat anak berada di kelas. Anak akan dapat belajar dengan baik jika memiliki kemampuan konsentrasi yang baik, dengan kata lain anak penyandang autis harus memiliki kebiasaaan untuk memfokuskan pikiran atau berkonsentrasi. Beberapa tahun terakhir ini para psikolog perkembangan semakin banyak mendapat rujukan dari dokter anak untuk mengkonsultasikan anak-anak usia 2-4 tahun yang mulai terlihat ketidakfokusan dalam belajar atau kesulitan dalam konsentrasi dengan gejala-gejala yang telah ada, yang sampai saat ini dapat menimbulkan kecemasan yang dalam bagi orang tua. Menurut DSM-IV-TR (diagnostic and Statical Manual of Mental Disorder, Fourth 
edition, textrevision) (dalam Rahardja, 2010), autism digolongkan ke dalam jenis kelainan perkembangan pervasif atau Pervasive Development Disorder (PDD). Diagnosis kelainan autistik dapat diberikan pada individu-individu yang menunjukan kelainan dalam interaksi sosial dan komunikasi serta ketidakmampuan dalam memunculkan perilaku yang harus sesuai dengan situasi sosialnya.

Penyesuaian pembelajaran anak yang memiliki kebutuhan khusus gangguan perkembangan, dalam hal ini sangat perlu untuk diperhatikan. Belajar dengan bermain sangatlah menyenangkan bagi anak yang memiliki kebutuhan khusus gangguan perkembangan. Melihat kondisi yang seperti ini maka diperlukan suatu permainan yang bisa meningkatkan kemampuan konsentrasi anak autis tidak hanya berpikir secara visual tetapi bisa berpikir secara verbal.

Permainan lasy merupakan suatu alat permainan edukatif (APE) yang bersifat konstruktif dan menyenangkan. Sifat konstruktif yang berguna bagi pemakai permainan ini adalah reproduktif, dimana anak memproduksi objek yang dilihatnya dalam kehidupan sehari-hari atau dalam media massa ke dalam bentuk konstruksinya. Tentunya dalam memainkannya diperlukan bimbingan untuk memberikan stimulus berupa imajinasi tentang obyek yang akan dibuat atau dibangun dengan menggunakan permainan lasy. Adapun fungsi utama permainan lasy secara umum adalah sebagai sarana untuk pengembangan kreatifitas, tetapi secara khusus permainan lasy dapat difungsikan untuk melatih kognisi (pengetahuan, melatih berfikir konsep, konsentrasi), melatih emosi, psikomotorik, persepsi sensor.

Permainan ini dapat dilakukan oleh kelompok atau individual. Permainan ini memerlukan alat peraga yaitu lasy yang bentuknya seperti huruf " $H$ ", dimana dalam permainan ini prinsipnya adalah interlock yakni saling mengunci. Pada permainan ini diperlukan konsentrasi atau perhatian saat proses bermain, sehingga permainan lasy ini dapat dijadikan sebagai media untuk mengintervensi anak autis untuk dapat meningkatkan konsentrasi terhadap tugas yang telah dicontohkan sebelumnya. Diharapkan anak dapat berkonsentrasi sesuai dengan keadaan kondisi disekitarnya, karena dengan pemberian stimulus yang tepat dan juga cara yang digunakan dikemas dalam sebuah permainan yang menarik akan mempermudah anak dalam memproses setiap informasi di dalam otaknya.

Berdasarkan latar belakang yang telah dipaparkan, maka peneliti mengambil judul penelitian "pengaruh permainan lasy terhadap peningkatan konsentrasi pada anak autis". Dengan rumusan masalah apakah permainan lasy berpengaruh terhadap konsentrasi anak autis. Penelitian ini bertujuan untuk mengetahui pengaruh permainan lasy terhadap peningkatan konsentrasi anak autis.

\section{METODE}

Penelitian ini dilakukan dengan menggunakan metode eksperimen. Model rancangan eksperimen yang digunakan adalah one group pretest-posttest. Pada rancangan ini perlakuan dikenakan pada suatu kelompok unit percobaan tertentu, dengan dilakukan dua kali pengukuran terhadap variabel terikat, yaitu sebelum dan sesudah perlakuan. Mengacu pada Arikunto (2006) maka penelitian dengan metode pre-eksperimen ini akan menggunakan rancangan sebagai berikut:

Tabel 1. Rancangan Eksperimen

\begin{tabular}{ccc}
\hline Pretest & Perlakuan & Posttest \\
\hline $\mathrm{O}_{1}$ & $\mathrm{X}$ & $\mathrm{O}_{2}$ \\
\hline
\end{tabular}


Keterangan:

$\mathrm{O}_{1}=$ pengukuran konsentrasi sebelum perlakuan

$\mathrm{X}=$ pemberian perlakuan berupa permainan lasy

$\mathrm{O}_{2}=$ pengukuran konsentrasi yang setelah perlakuan

\section{Partisipan}

Subjek penelitian ini adalah anak dengan penyandang autis di salah satu pusat terapi di Driyorejo Gresik yang memiliki karakteristik, yaitu (1) lemah dalam berkonsentrasi; (2) tidak mengalami hambatan selain autis; (3) tidak dalam pengobatan biomedis; (4) usia 8 tahun. Lima anak autis berhasil direkrut dalam penelitian ini. Selain telah memenuhi kriteria subjek penelitian yang ditetapkan, peneliti juga menggunakan rekam medik yang diperoleh dari pemeriksaan tumbuh kembang anak, untuk memastikan bahwa kelima anak dalam penelitian ini adalah penyandang autis.

\section{Prosedur}

Prosedur pelaksanaan eksperimen ini didasarkan pada modul permainan lasy. Permainan lasy ini secara garis besar terdiri atas dua bagian yaitu pengenalan dan memusatkan perhatian terhadap instruksi. Masing-masing bagian terdiri dari tahap permainan lasy.

Tahap pertama, permainan lasy yang dilakukan adalah mengenalkan komponen yang ada dalam permainan lasy beserta warna-warna yang terdapat dalam permainan lasy yang ditunjukkan dalam bentuk merakit, menggunakan dan fungsinya.

Tahap kedua, anak diberikan sebuah contoh salah satu bentuk bangunan yang ada dalam modul permainan lasy, kemudian anak mulai diperintahkan untuk menirukan. Masing-masing tahap dilakukan selama satu sesi, selama 8 kali pertemuan dengan setiap pertemuan 45 menit. Dalam pelaksanaanya peneliti dibantu oleh dua observer dan bentuk penyajiannya dilakukan secara klasikal.

Keseluruhan tahapan pada modul penelitian ini diujicobakan terlebih dahulu dengan subjek lain yang hampir memiliki karakteristik yang sama untuk memberikan pengalaman dan pemahaman yang lebih dalam bagi peneliti tentang alur serta materi yang akan digunakan.

Peran peneliti dalam penelitian ini lebih difokuskan sebagai teman atau patner dalam bermain, tetapi disisi lain ada beberapa tugas yang harus diselesaikan ketika dalam permainan lasy: (1) memberi motivasi subjek untuk lebih cepat mengingat cara membentuk bangunan; (2) memberikan instruksi: (3) memberikan contoh bentuk bangunan yang akan dibuat oleh subjek; serta (4) memberikan bantuan kepada subjek yang mengalami kesulitan dalam membuat sebuah bentuk bangun.

\section{Teknik Pengumpulan Data}

Teknik pengumpulan data yang digunakan dalam penelitian ini menggunakan dua metode yaitu: observasi dan dokumentasi.

Metode observasi digunakan untuk menentukan subjek penelitian observasi dilakukan dengan melakukan pengamatan terhadap subjek dan melihat data laporan perkembangan subjek untuk mencari tahapan pola perkembangan anak autis yang mengalami gangguan pemusatan perhatian atau sulit berkonsentrasi. Penelitian ini menggunakan sistem pencatatan data dengan prosedur pencatatan melalui produk permanen. Permanen yang dimaksud dalam penelitian ini adalah lembar penilaian yang berisikan aspek-aspek gangguan konsentrasi yang diadaptasi dari DSM-IV-TR (American Psychiatric Associaton, 2000) mengenai gangguan pemusatan perhatian atau gangguan konsentrasi. 
Observasi berstruktur (pengamatan berstruktur) menurut Nazir (2003) adalah peneliti telah mengetahui aspek dari aktifitas yang diamati yang relevan dengan masalah serta tujuan peneliti, dengan pengungkapan yang sistematis untuk menguji hipotesisnya. Observasi yang dilakukan dilengkapi dengan panduan observasi yang berisi aspek-aspek yang akan diamati. Observasi dilakukan pada saat pretest (sebelum perlakuan) dan posttest (setelah perlakuan) untuk mengetahui peningkatan konsentrasi anak autis.

Teknik dokumentasi dilakukan dengan mencari data mengenai hal-hal atau variabel yang berupa catatan, transkrip, buku, surat kabar, majalah, agenda dan sebagainya (Arikunto, 2006). Dokumentasi yang digunakan dalam penelitian ini adalah foto dalam setiap kegiatan penelitian serta rekam medik subjek dalam kegiatan penelitian. Tujuan dalam dokumentasi adalah sebagai salah satu cara untuk membantu mengetahui perkembangan kemampuan konsentrasi anak autis pada saat penelitian. Dokumentasi di dalam penelitian ini juga sebagai pelengkap data dan tidak dianalisis, sedangkan rekam medik subjek digunakan untuk menentukan subjek.

Dalam penelitian ini menggunakan rating scale untuk mengukur tingkat konsentrasi yang mengacu pada DSM-IVTR (American Psychiatric Association, 2000). Penilaian diberikan berdasarkan tinggi rendahnya skor yang diperoleh skor antara 14. Semakin tinggi skor yang diperoleh semakin tinggi tingkat konsentrasi anak. Proses validasi dilakukan dengan cara menunjukkan alat ukur rating scale tingkat konsentrasi kepada 3 orang ahli yaitu terapis permainan lasy, psikolog perkembangan dan psikolog pendidikan. Ketiga ahli tersebut diminta untuk menilai apakah alat ukur ini mampu dan tepat mengukur tingkat konsentrasi anak autis. Berdasarkan pendapat ketiga ahli tersebut dapat disimpulakan bahwa pada dasarnya alat tersebut dapat digunakan mengukur tingkat konsentrasi anak autis, dengan catatan instruksi harus jelas. Dasar pertimbangan rasional yang dinyatakan adalah alat ukur mampu mengukur tingkat konsentrasi sesuai definisi gangguan pemusatan perhatian, tepat untuk anak autis. Berdasarkan pendapat ketiga ahli tersebut maka alat ukur dianggap valid. Perhitungan reliabilitas rating scale tingkat konsentrasi menggunakan Kappa dari Cohen (2001). Uji reliabilitas menunjukkan koefisien tingkat konsistensi suatu alat ukur atau $\mathrm{K}$ sebesar 0,605. Ini berarti menunjukkan dalam kategori memuaskan (berdasarkan tabel Fleis, dalam Widhiarso, 2005).

\section{Teknik Analisis Data}

Analisis data statistik uji peringkat bertanda Wilcoxon (Wilcoxon Signed Rank Test) menggunakan bantuan program SPSS 17.0 for windows digunakan dalam penelitian ini untuk menguji hipotesis. Teknik ini merupakan penyempurnaan dari uji tanda. Kalau dalam uji tanda besarnya nilai angka antara positif dan negatif tidak diperhitungkan, akan tetapi dalam teknik ini diperhitungkan (Sugiyono, 2010). Berikut ini langkah-langkah perhitungan Wilcoxon Signed Rank Test: 1). mencari besarnya beda yang menunjukkan selisih skor antara pasangan-pasangan sebelum dan sesudah diberikan perlakuan (harus ada satu beda untuk tiap pasangan skor); 2) jenjang ranking beda tanpa mengindahkan tandanya $(+)$ atau (), dengan memberikan jenjang kesatu unutuk selisih terkecil, jenjang kedua untuk selisih terkecil berikutnya, dan seterusnya; 3 ) untuk tiap jenjang diberi tanda perbedaan plus $(+)$ atau minus (-); 4) menjumlahkan jenjang untu perbedaan plus dan jumlahkan jenjang untuk minus. Jika jumlah jenjang plus sama dengan jumlah jenjang minus hal ini dapat disimpulkan bahwa tidak ada perbedaan 
antara sebelum dan sesudah perlakuan. Jika skor suatu pasangan tertentu ternyata sama, maka pasangan itu dibuang atau tidak dipakai dasar perhitungan. Jika ditemui dua atau lebih perbedaan ternyata menempati jenjang yang sama, maka jenjang itu dicari rata-ratanya.

\section{HASIL}

Hasil analisis terhadap data antara sebelum dan setelah perlakuan tergambar sebagai berikut:
Berdasarkan tabel 3, dapat dikatakan dari tabel diatas dapat disimpulkan bahwa peningkatan konsentrasi yang signifikan dialami oleh MY sebesar 24,35\%, TN sebesar 23,07 \%, AN sebesar $20,51 \%$, NN sebesar $16,66 \%$, dan 0

GN sebesar $15,38 \%$.

Berdasarkan penghitungan statistik Wilcoxon diperoleh hasil nilai $\mathrm{Z}$ hitung sebesar -2.023 dan signifikansinya sebesar 0,043, karena signifikansi sebesar 0,043 lebih kecil daripada $0,05(0,043<0.05)$, sehingga terdapat perbedaan antara sebelum dan

Tabel 2. Deskripsi Data Penelitian

\begin{tabular}{cccccc}
\hline & $\mathrm{N}$ & Minim & Maks & Mean & Std. Deviasi \\
\hline Pretetst & 5 & 17.00 & 21.00 & 18.2000 & 1.64317 \\
Posttest & 5 & 30.00 & 39.00 & 33.8000 & 3.89872 \\
\hline
\end{tabular}

Tabel 3. Prosentase dan Rank Peningkatan Konsentrasi

\begin{tabular}{|c|c|c|c|c|c|c|}
\hline No & Subjek & Pretest & Posttest & Selisih & $\%$ & Rank \\
\hline 1. & MY & 17 & 36 & 19 & 24,35 & 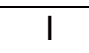 \\
\hline 2. & GN & 18 & 30 & 12 & 15,38 & V \\
\hline 3. & AN & 18 & 34 & 16 & 20,51 & III \\
\hline 4. & TN & 21 & 39 & 18 & 23,07 & II \\
\hline 5. & NN & 17 & 30 & 13 & 16,66 & IV \\
\hline \multicolumn{2}{|c|}{ Jumlah } & 91 & 169 & 78 & 100 & \\
\hline
\end{tabular}

Tabel 4. Hasil Analisis Uji Wilcoxon

\begin{tabular}{ccccc}
\hline & & $\mathrm{N}$ & Mean Rank & Sum of Rank \\
\hline Posttest- & Negative rank & $0^{\mathrm{a}}$ & .00 & .00 \\
Pretest & Positif rank & $5^{\mathrm{b}}$ & 3.00 & 15.00 \\
& Ties & $0^{\mathrm{c}}$ & & \\
& Total & 5 & Posttest-Prettest \\
\hline \multicolumn{4}{c}{ Test statistics } \\
\hline Asymp. Sig (2 tailed)
\end{tabular}

Tabel 2 deskripsi data penelitian tersebut menunjukkan bahwa rata-rata hasil pretest adalah 18. Nilai tertinggi dalam pretest tersebut adalah 21 dan terendah 17. Rata-rata hasil posttest adalah 34 dengan nilai tertinggi dalam posttest adalah 39 dan terendah 30. sesudah diberikannya perlakuan. Hal ini berarti terdapat pengaruh permainan lasy terhadap peningkatan konsentrasi pada anak autis. Sejalan dengan hasil yang diperoleh, maka hipotesis bahwa ada pengaruh permainan lasy terhadap peningkatan 
konsentrasi pada anak autis dapat diterima.

\section{PEMBAHASAN}

Temuan dalam penelitian ini menunjukkan bahwa pemberian permainan lasy berpengaruh pada peningkatan konsentrasi pada anak autis. Hal ini dapat dimunginkan karena permainan ini menyenangkan bagi mereka sehingga mereka berusaha menyelesaikan tugas-tugas yang diberikan dalam permainan tersebut sehingga konsentrasi mereka meningkat.

Peningkatan konsentrasi dalam penelitian ini mengandung arti bahwa dengan menggunakan metode bermain lasy dapat berdampak positif terhadap faktor-faktor yang mempengaruhi kognitif yang dimiliki subjek. Hal ini setara yang diutarakan oleh Widyawati (2005), individu yang menyandang autis mengalami gangguan atau keterlambatan dalam bidang kognitif, bahasa, interaksi sosial dan perilaku. Oleh karena itu perlakuan khusus latihan-latihan yang dibimbing oleh para terapis sangatlah diperlukah agar dapat melakukan gerak dan memahami suatu konsep yang datang melalui otaknya dengan cara bermain yang bersifat menggembirakan. Temuan lain yang menarik dalam penelitian ini adalah ketika bermain dapat dilihat dari subjek dapat menyelesaikan bentuk bangunan kemudian berimajinasi bersama dengan teman-temannya (subjek lain) dan dapat bersosialisasi (membantu subjek lain yang belum selesai atau terlambat dalam mengikuti instruksi).

Ketika terdapat rasa aman, nyaman, dan berada pada suasana yang menyenangkan dalam proses bermain maupun belajar, anak akan lebih mudah dalam menjalankan proses bermain dan proses belajar. Apabila suasana kondusif sudah terbentuk maka akan lebih mudah bagi terapis untuk memberikan instruksi dan respon yang diinginkan akan segera dimunculkan, hal ini dapat dilihat dari subjek yang dengan cepat akan mengikuti instruksi yang diberikan. Sebaliknya, jika dalam proses bermain maupun belajar dalam kondisi yang kurang kondusif atupun anak kurang merasa keadaan fisik kurang sehat, kemampuan belajarnya rendah, anak berada pada kondisi yang tidak stabil yang artinya tidak nyaman merasa ketakutan karena ada orang baru maka apapun yang diberikan tidak akan masuk dan respon yang diinginkan tidak muncul atau sulit untuk mengikuti instruksi yang diberikan. Perilaku-perilaku anak autis yang tidak dapat ditebak oleh orang-orang sekitar dapat membuat kita menyadari bahwa anak-anak berkebutuhan khusus dalam hal ini anak autis memerlukan orang-orang yang dapat memahami dan mengerti apa yang diinginkan anak tersebut. Hal ini juga berlaku dalam proses bermain.

Ketika kepatuhan dan kebiasaaan itu sudah dimiliki oleh anak autis maka akan dengan mudah memberikan instruksi serta merespon apa yang diinstruksikan. Memfokuskan perhatian atau konsentrasi merupakan hal yang terpenting dalam suatu peristiwa dalam hal ini yang dimaksudkan adalah ketika anak didalam kelas dengan mudah menerima informasi atau instruksi dari guru. Dengan demikian dari paparan dan bukti empiris diatas dapat disimpulkan bahwa permainan lasy berpengaruh terhadap peningkatan konsentrasi pada anak autis.

\section{SIMPULAN}

Penelitian ini menyimpulkan bahwa pada penelitian terhadap lima (5) anak autis di salah satu pusat terapi dengan menggunakan permainan lasy, dapat meningkatkan konsentrasi anak autis. Permainan lasy ini berdampak postif pada peningkatan konsentrasi anak autis, dapat terlihat pada subjek yang diberi perlakuan cenderung lebih cepat dalam memfokuskan perhatian daripada siswa yang lain. Sehingga dapat disimpulkan 
bahwa permainan lasy terbukti efektif untuk meningkatkan konsentrasi pada anak autis.

\section{SARAN}

Diharapkan dalam penelitian selanjutnya menggunakan subjek lebih banyak lagi. Selain itu penelitian selanjutnya diharapkan dapat menambahkan atau mengkhususkan pada berapa lama subjek telah berada dalam pusat terapi ataupun jenis autis. Hal ini dimaksudkan agar didapat hasil yang optimal. Disamping itu juga ada manfaat dan kegunaan, khususnya bagi anak autis. Permainan inipun dapat dijadikan dijadikan suatu program refrensi alternatif untuk meningkatkan konsentrasi pada anak autis. Selain itu dapat dilakukan dengan menambah frekwensi permainan guna lebih meningkatkan konsentrasi anak autis dan menstimulasi kognitifnya serta dapat meningkatkan ketrampilan sosialnya.

\section{DAFTAR PUSTAKA}

American Psychiatric Association. (2000): Diagnostic and Statistical Manual of Mental Disorder, ed.4, text revision (DSMIV-TR). Washington DC: The Association.

Arikunto, S. (2006). Prosedur Penelitian Suatu Pendekatan Praktek. Jakarta: Rineka Cipta

Bektiningsih, K. (2009). Program Terapi Anak Autis di SLB Negeri Semarang. Jurnal Pendidikan, 39 (2), 85-110. Diakses dari http://www.unnes.ac.id pada tanggal 24 Juli 2013.

Budiman, M. (2001). Langkah Awal Menanggulangi Autisrne. Jakarta: Nirmala.

Cohen, B.H. (2001). Explaining Psychological Statistics. $\left(2^{\text {nd }}\right.$ ed). New York: John Wiley \& Sons, Inc.

Dharmono. (2010). Buku Ajar Psikiatri. Jakarta: Badan Penerbit FKUI.

Hadiyanto, Y. (2003). Autisme. Diakses dari http://.www.autism.society.org. pada 13 November 2012.
Mustajib, A. (2010). Sejarah Perkembangan Autis. Diakses dari http://www.gelombang otak.com pada tanggal 28 Februari 2012.

Nazir, M (2003). Metode Penelitian. Jakarta : Salemba Empat

Ninggsih. (2007). Autisma: Petunuk Praktis dan Pedoman Materi Untuk Mengjar Anak Normal, Autis dan Perilaku Lain. Jakarta: Gramedia

Rahardja, D. Sujarwanto. (2010). Pengantar Pendidikan Luar Biasa. Surabaya: UD .Mapan

Sugiyono. (2010). Statistik untuk Penelitian. Jakarta : Alfabeta

Widhiarso, W (2005). Mengestimasi Realibilitas. Yogyakarta : Fakultas Psikologi UGM

Widyawati. (2005). Deteksi anak autis. Diakses dari http://www.balipost.co.id/ balipostcetak/ 2004/11/14/ce3.html pada tanggal 12 Oktober 2012. 